\title{
PENGARUH JARAK TANAM JAGUNG TERHADAP PERTUMBUHAN DAN HASIL JAGUNG SERTA KACANG TANAH YANG DITANAM SEBAGAI TANAMAN SELA
}

\author{
Murdaningsih $^{1}$, Ambrosius Lai $^{2}$ \\ Ningsih_murda@yahoo.co.id
}

Program Studi Agroteknologi, Fakultas Pertanian-Universitas Flores

\begin{abstract}
ABSTRAK
This research aims to find the effect of planting distance on the growth and yield of corn plantswhich were planted with peanut as intercropping plant, and the impact on yield of peanuts planted as intercropping plant as well as to knowplantingdistance for corn and peanut.

The experimental design used wasRandomized Block Design with six treatments namely J1; $55 \mathrm{~cm} \mathrm{x} 40 \mathrm{~cm}, \mathrm{~J} 2 ; 60 \mathrm{~cm} \mathrm{x} 40 \mathrm{~cm}, \mathrm{~J} 3 ; 65 \mathrm{~cm}$ x $40 \mathrm{~cm}, \mathrm{~J} 4 ; 70 \mathrm{~cm}$ x $40 \mathrm{~cm}$, $\mathrm{J} 5 ; 75 \mathrm{~cm} \mathrm{x} 40 \mathrm{~cm}$, and J6; $80 \mathrm{~cm} \times 40 \mathrm{~cm}$, while peanuts are planted in the central part of the line, and the corns rows are repeated four times so that there are 24 compartments of research.

Results of the study indicated that there is significant effect on the growth and yield of corn at a distance of $75 \mathrm{~cm} \mathrm{x} 40 \mathrm{~cm}$ as well as peanuts planted as a intercropping plant with high corn sidelines range from $32,08-132,55 \mathrm{~cm}$, number of leaves revolves around $4.17-9.25$ strands, leaf area range from $25,84-52.80 \mathrm{~cm}$, corncobdiameter of $10.09 \mathrm{~cm}$, corncob weight $\tan ^{-1} 171,33$ grmand ha ${ }^{1-} 5,68$ ton, dry weightgrain of corn $\tan ^{1-} 80,13$ grmand ha ${ }^{1-} 3,80$ ton, as well as weightof 100 grain of corn is 32,17 grm, whereas number of pods of peanut is 26,63 polong, pods weight $\tan ^{1-}$ 88,13 grmand ha ${ }^{1-} 3,17$ ton, dry weight of corn $\tan ^{1-} 31,25$ grmand ha ${ }^{1-} 1,31$ ton, and weight of 100 corn grainsare 19,22 grm.
\end{abstract}

Keywords: planting distance, intercropping plant, corn, peanuts

\section{PENDAHULUAN}

Jagung (Zea mays L) merupakan salah satu tanaman pangan dunia yang terpenting, selain gandum dan padi. Petani di beberapa Desa di Kabupaten Ende melakukan budidaya jagung untuk memenuhi kebutuhan hidup dan meningkatkan pendapatan secara ekonomi, namun sampai sekarang produksi yang dicapai masih sangat rendah.

Produksi jagung di Kabupaten Ende dua tahun terakhir adalah pada tahun 2010 mencapai $9.949,59$ ton dengan luas tanam 4.675,94 ha serta luas panen $3.644,95$ ha dan rata-rata produksinya ialah 1,12 ton biji pipilan/ha sedangkan pada tahun 2011 ialah 7.935,29 ton dengan luas tanam 
Murdaningsih: Pengaruh jarak tanam jagung terhadap pertumbuhan dan hasil jagung serta kacang tanah yang ditanam sebagai tanaman sela

5.308,04 ha serta luas panen 4.936,48 ha dan rata-rata produksinya 1,8 ton biji pipilan/ha, sementara kebutuhan jagung yang digunakan untuk konsumsi, benih dan kebutuhan lain ialah 11.091,03 ton (BKP3, 2010 dan 2011). Rendahnya produksi dan pendapatan petani tersebut dipengaruhi oleh beberapa faktor antara lain petani belum melakukan pengolahan tanah secara baik, belum melakukan pengaturan jarak tanam yang tepat, pemeliharaan tanaman budidaya yang kurang baik serta teknologi atau metode yang digunakan masih kurang tepat.

Faktor jarak tanam merupakan salah satu faktor penyebab utama dari rendahnya produksi. Berdasarkan pengamatan dilapang, jarak tanam yang sering digunakan oleh petani ialah $55 \mathrm{~cm}$ x $40 \mathrm{~cm}$, dan metode pola tanam yang digunakan ialah pola monokultur sedangkan jarak tanam untuk tanaman jagung yang sesuai adalah $75 \mathrm{~cm}$ x $40 \mathrm{~cm}$ (Praptomo, dkk, 2010). Salah satu upaya yang dapat dilakukan dalam mengatasi rendahnya produksi jagung adalah intensifikasi dan diversifikasi serta pengaturan jarak tanam yang sesuai dan menggunakan metode atau pola sistem tanaman sela.
Pola tanam tanaman sela yang akan digunakan ialah jagung dengan kacang tanah, kedua komoditi inimerupakan kombinasi antara tanaman dengan tajuk tinggi berakar dalam (jagung) dengan tajuk rendah berakar dangkal (kacang tanah) disamping itu, tanaman jagung merupakan tanaman yang banyak membutuhkan unsur Nitrogen $(\mathrm{N})$ sedangkan kacang tanah merupakan tanaman yang mampu mengikat atau memfiksasi unsur $\mathrm{N}$ dari udara atau dapat dikatakan bahwa tanaman kacang tanah adalah tanaman yang banyak menghasilkan unsur N. Selain itu, tanaman jagung merupakan tanaman pangan yang dapat ditanam campur dengan tanaman lain karena tajuknya kurang lebar dan tidak rimbun sehingga tidak menghalang cahaya yang masuk, sehingga tanaman lain juga mendapatkan cahaya untuk proses fotosintesis dan tidak menghalangi pertumbuhan dan perkembangan tanaman lain.

Selama ini petani sudah melakukan penanaman dengan sistem campuran antara beberapa jenis tanaman, namun belum melakukan pengaturan jarak tanam yang baik (Sunarta, 2009). Berdasarkan 
Murdaningsih: Pengaruh jarak tanam jagung terhadap pertumbuhan dan hasil jagung serta kacang tanah yang ditanam sebagai tanaman sela

pengamatan di lapang ditemukan beberapa petani menanam jagung menggunakan sistem tanaman sela dengan tanaman kacang-kacangan namun jarak tanam yang digunakan terlalu rapat yaitu $55 \mathrm{~cm} \times 40 \mathrm{~cm}$, sehingga mudah terjadi persaingan unsur hara dan cahaya, sedangkan jarak tanam jagung yang ideal ialah $75 \mathrm{~cm} \mathrm{x}$ $40 \mathrm{~cm}$ (Anonymus, 2005).

Penelitian ini bertujuan untuk mengetahui pengaruh yang terjadi pada pertumbuhan dan hasil tanaman jagung yang ditanam dengan tanaman kacang tanah sebagai tanaman sela, mengetahui pengaruh yang terjadi pada pertumbuhan dan hasil tanaman kacang tanah yang ditanam sebagai tanaman sela dan mengetahui jarak tanam yang ideal untuk jagung yang ditanam dengan kacang tanah sebagai tanaman sela.

\section{METODE PENELITIAN}

\section{Tempat dan Waktu Penelitian}

Penelitian dilaksanakan di kebun percobaan Fakultas Pertanian yang berada di Kelurahan Lokoboko, Kecamatan Ndona, Kabupaten Ende. Penelitian dari bulan Agustus 2012 sampai dengan bulan Januari 2013.

\section{Bahan dan Alat}

Bahan yang digunakan antara lain: benih jagung varietas Arjuna, benih kacang tanah varietas Bison, dan pupuk kandang ayam. Alat yang digunakan antara lain: cangkul, parang, ember, tugal, gembor, hand sprayer, meter kain, timbangan, tali raffia, dan alat tulis menulis.

\section{Rancangan Penelitian}

Penelitian menggunakan Rancangan Acak Kelompok (RAK) yang terdiri dari 6 perlakuan jarak tanam yaitu $\mathrm{J} 1=55 \mathrm{~cm} \times 40 \mathrm{~cm}, \mathrm{~J} 2=$ $60 \mathrm{~cm} \times 40 \mathrm{~cm}, \mathrm{~J} 3=65 \mathrm{~cm} \times 40 \mathrm{~cm}, \mathrm{~J} 4=$ $70 \mathrm{~cm} \times 40 \mathrm{~cm}, \mathrm{~J} 5=75 \mathrm{~cm} \times 40 \mathrm{~cm}, \mathrm{~J} 6=$ $80 \mathrm{~cm}$ x $40 \mathrm{~cm}$. Ulangan sebanyak 4 kali.

\section{PelaksanaanPenelitian}

\section{Persiapan Lahan dan pembuatan bedeng.}

Lahan diolah dengan kedalaman olah tanah $30 \mathrm{~cm}$. Kemudian Petakpetak penelitian dibuat dengan ukuran panjang 3,6 $\mathrm{m}$ dan lebar 1,6 $\mathrm{m}$ serta tinggi $30 \mathrm{~cm}$ sedangkan drainasenya dengan lebar 25-30 $\mathrm{cm}$ dan dalam 30 $\mathrm{cm}$.

\section{Pemupukan.}

Pemupukan dengan menggunakan pupuk kandang (kotoran ayam) sebanyak 20 ton/ha yang diaplikasikan setelah pengolahan tanah dan sebelum pembuatan petak. 
Murdaningsih: Pengaruh jarak tanam jagung terhadap pertumbuhan dan hasil jagung serta kacang tanah yang ditanam sebagai tanaman sela

\section{Penanaman.}

Setiap lubang tanam untuk tanaman jagung ditanam 2 butir per lubang dengan jarak tanam: $\mathrm{J} 1=55 \mathrm{~cm}$ $\mathrm{x} 40 \mathrm{~cm}, \mathrm{~J} 2=60 \mathrm{~cm} \times 40 \mathrm{~cm}, \mathrm{~J} 3=65 \mathrm{~cm}$ $\mathrm{x} 40 \mathrm{~cm}, \mathrm{~J} 4=70 \mathrm{~cm} \times 40 \mathrm{~cm}, \mathrm{~J} 5=75 \mathrm{~cm}$ $\mathrm{x} 40 \mathrm{~cm}$, dan $\mathrm{J} 6=80 \mathrm{~cm} \times 40 \mathrm{~cm}$, sedangkan kacang tanah sebagai tanaman sela ditanam 2-3 butir per lubangyang ditanam diantara tanaman jagung.

\section{Pemeliharaan Tanaman.}

Pemeliharaan tanaman meliputi penyiraman, penyiangan, pembumbunan, dan pengendalian hama dan penyakit.

Panen.

Jagung dipanen setelah berumur 120 hari terhitung sejak tanam. Kacang tanah dipanen setelah berumur 130 hari.

\section{Variabel Pengamatan}

Variabel yang diamati adalah tinggi tanaman, jumlah daun, luas daun, indeks luas daun umur 21, 28, 35, 42, 49 hstserta diameter tongkol, diameter tongkol, berat tongkol tanaman ${ }^{1}$, berat tongkol ha ${ }^{1}$, berat kering jagung tanaman ${ }^{1}$, berat kering jagung ha ${ }^{1}$, berat 100 butir jagung, jumlah polong kacang tanah tanaman ${ }^{1}$, berat polong kacang tanah tanaman 1, Berat Polong Kacang Tanah ha ${ }^{1}$,Berat kering kacang tanah tanaman ${ }^{1}$, Berat kering kacang tanah ha ${ }^{1}$, dan berat 100 butir biji kacang tanah.

\section{Analisis Data}

Data hasil pengamatan dianalisis secara statistika dengan menggunakan analisis varian (sidik ragam) sesuai dengan rancangan yang digunakan. Apabila perlakuan menunjukkan pengaruh nyata terhadap variabel yang diamati maka dlilanjutkan dengan uji BNT 5\% (Gomez dan Gomez, 1995).

\section{HASIL DAN PEMBAHASAN}

\section{Tinggi tanaman}

Data hasil analisis sidik ragam menunjukan bahwa jarak tanam memberikan pengaruh yang sangat nyata terhadap tinggi tanaman pada setiap umur pengamatan (Tabel 4.1).

Hasil diatas, menunjukan bahwa perlakuan J5 memberikan nilai tertinggi kecuali pada umur 49 hst, karena pada umur tersebut tanaman mulai beralih masa dari fase fegetatif ke fase generative disebabkan oleh jarak tanam yang digunakan sesuai sehingga tidak mudah terjadi persaingan unsur hara tanah, intensitas cahaya, air serta unsurunsur lain yang turut memacu pertumbuhan tanaman, dan juga salah satunya disebabkan karena sistem tanam yang digunakan 
Murdaningsih: Pengaruh jarak tanam jagung terhadap pertumbuhan dan hasil jagung serta kacang tanah yang ditanam sebagai tanaman sela

Tabel 4.1 Rataan Tinggi Tanaman Jagung Pada Setiap Umur Pengamatan

\begin{tabular}{ccccccc}
\hline \multirow{2}{*}{ Perlakuan } & \multicolumn{5}{c}{ Tinggi Tanaman $(\mathrm{cm})$ pada setiap umur pengamatan (hst) } \\
\cline { 2 - 7 } & 14 & 21 & 28 & 35 & 42 & 49 \\
\hline J1 & $16,58 \mathrm{f}$ & $26,42 \mathrm{f}$ & $38,00 \mathrm{f}$ & $60,00 \mathrm{f}$ & $81,00 \mathrm{f}$ & $106,25 \mathrm{f}$ \\
J2 & $20,50 \mathrm{e}$ & $27,72 \mathrm{e}$ & $42,33 \mathrm{e}$ & $61,50 \mathrm{e}$ & $82,83 \mathrm{e}$ & $110,53 \mathrm{e}$ \\
J3 & $23,00 \mathrm{~d}$ & $31,17 \mathrm{~d}$ & $44,50 \mathrm{~d}$ & $64,64 \mathrm{~d}$ & $84,42 \mathrm{~d}$ & $116,08 \mathrm{~d}$ \\
J4 & $24,58 \mathrm{c}$ & $33,83 \mathrm{c}$ & $46,17 \mathrm{c}$ & $67,67 \mathrm{c}$ & $86,22 \mathrm{c}$ & $121,33 \mathrm{c}$ \\
J5 & $32,08 \mathrm{a}$ & $41,41 \mathrm{a}$ & $56,50 \mathrm{a}$ & $71,75 \mathrm{a}$ & $90,44 \mathrm{a}$ & $132,55 \mathrm{~b}$ \\
J6 & $29,08 \mathrm{~b}$ & $35,08 \mathrm{~b}$ & $54,42 \mathrm{~b}$ & $69,09 \mathrm{~b}$ & $88,28 \mathrm{~b}$ & $136,46 \mathrm{a}$ \\
\hline BNT 5\% & 0,38 & 0,92 & 0,42 & 0,77 & 0,37 & 2,98 \\
\hline
\end{tabular}

Keterangan: Angka-angka yang diikuti oleh huruf yang sama pada kolom yang sama menunjukan tidak berbeda nyata pada taraf uji BNT 5\%

. Sistem yang digunakan ialah sistem tanam tanaman sela, dalam hal ini jagung sebagai tanaman utama dan kacang tanah sebagai tanaman sela, merupakan kombinasi antara tanaman leguminosa (C4) dengan tanaman bijibijian (C3) dimana tanaman biji-bijian (kacang tanah) memiliki bintil-bintil akar yang mampu mengikat atau memfiksasi nitrogen (N) dari udara, sedangkan tanaman leguminosa (jagung) merupakan tanaman yang sangat membutuhkan unsur $\mathrm{N}$ dalam jumlah yang cukup besar (Koswara, dalam Erniyani 2008).

\section{Jumlah daun}

Hasil analisis sidik ragam menunjukan bahwa jarak tanam berpengaruhnyata terhadap jumlah daun pada setiap umur pengamatan (Tabel 4.2).

Tabel 4.2. Rataan Jumlah Daun Jagung Pada Setiap Umur Pengamatan.

\begin{tabular}{ccccccc}
\hline \multirow{2}{*}{ Perlakuan } & \multicolumn{5}{c}{ Jumlah Daun (helai) pada setiap Umur Pengamatan (hst) } \\
\cline { 2 - 7 } & 14 & 21 & 28 & 35 & 42 & 49 \\
\hline J1 & $3,63 \mathrm{~d}$ & $5,38 \mathrm{~b}$ & $8,08 \mathrm{e}$ & $8,08 \mathrm{~d}$ & $8,88 \mathrm{e}$ & $9,00 \mathrm{c}$ \\
J2 & $4,08 \mathrm{c}$ & $6,17 \mathrm{a}$ & $8,17 \mathrm{~d}$ & $8,17 \mathrm{c}$ & $9,08 \mathrm{~cd}$ & $9,00 \mathrm{c}$ \\
J3 & $4,08 \mathrm{c}$ & $6,25 \mathrm{a}$ & $8,25 \mathrm{c}$ & $8,17 \mathrm{c}$ & $9,00 \mathrm{~d}$ & $9,00 \mathrm{c}$ \\
J4 & $4,17 \mathrm{~b}$ & $6,17 \mathrm{a}$ & $8,17 \mathrm{~d}$ & $8,25 \mathrm{bc}$ & $9,17 \mathrm{c}$ & $9,25 \mathrm{~b}$ \\
J5 & $4,17 \mathrm{~b}$ & $6,58 \mathrm{a}$ & $8,58 \mathrm{a}$ & $8,58 \mathrm{a}$ & $9,75 \mathrm{a}$ & $9,25 \mathrm{~b}$ \\
J6 & $4,25 \mathrm{a}$ & $6,42 \mathrm{a}$ & $8,42 \mathrm{~b}$ & $8,33 \mathrm{~b}$ & $9,33 \mathrm{~b}$ & $9,75 \mathrm{a}$ \\
\hline BNT 5\% & 0,07 & 0,51 & 0,04 & 0,09 & 0,09 & 0,14 \\
\hline
\end{tabular}

Keterangan: Angka-angka yang diikuti oleh huruf yang sama pada kolom yang sama menunjukan tidak berbeda nyata pada taraf uji BNT 5\%

Hasil diatas menunjukkan yang paling tinggi ialah pada perlakuan bahwapada umur 14 hst jumlah daun J6, hal ini disebabkan karena pada umur 
Murdaningsih: Pengaruh jarak tanam jagung terhadap pertumbuhan dan hasil jagung serta kacang tanah yang ditanam sebagai tanaman sela

14 hst belum terjadi persaingan karena umur dan kapasitas dalam penyerapan unsur hara masih sangat rendah, sedangkan pada umur 21 hst perlakuan J2-J6 tidak berbeda nyata, hal ini disebabkan karena tanaman jagung di tanam pada hari yang sama dan memiliki daya tumbuh yang sama. Pada umur 28-42 hst kapasitas penyerapan unsur hara semakin tinggi guna mempertahankan pertumbuhan dan perkembangannya.

\section{Luas Daun}

Hasil analisis sidik ragam menunjukan bahwa jarak tanam jagung memberikan pengaruh yang sangat nyata pada luas daun untuk setiap umur pengamatan (Tabel 4.3).

Table 4.3 Rataan Luas Daun Jagung Pada Setiap Umur Pengamatan

\begin{tabular}{ccccccc}
\hline & \multicolumn{7}{c}{ Luas Daun $(\mathrm{cm})$ Pada Umur Pengamatan } \\
\cline { 2 - 7 } Perlakuan & 14 & 21 & 28 & 35 & 42 & 49 \\
\hline J1 & $204,10 \mathrm{f}$ & $306,17 \mathrm{f}$ & $446,75 \mathrm{f}$ & $558,39 \mathrm{f}$ & $697,93 \mathrm{f}$ & $814,39 \mathrm{f}$ \\
J2 & $214,33 \mathrm{e}$ & $321,54 \mathrm{e}$ & $469,13 \mathrm{e}$ & $586,33 \mathrm{e}$ & $732,99 \mathrm{e}$ & $855,18 \mathrm{e}$ \\
J3 & $216,82 \mathrm{~d}$ & $325,28 \mathrm{~d}$ & $474,64 \mathrm{~d}$ & $593,23 \mathrm{~d}$ & $740,05 \mathrm{~d}$ & $863,45 \mathrm{~d}$ \\
J4 & $233,32 \mathrm{c}$ & $349,98 \mathrm{c}$ & $527,18 \mathrm{c}$ & $658,97 \mathrm{c}$ & $823,66 \mathrm{c}$ & $950,50 \mathrm{c}$ \\
J5 & $266,95 \mathrm{a}$ & $400,67 \mathrm{a}$ & $583,42 \mathrm{a}$ & $729,17 \mathrm{a}$ & $911,47 \mathrm{a}$ & $995,53 \mathrm{a}$ \\
J6 & $258,03 \mathrm{~b}$ & $387,12 \mathrm{~b}$ & $564,83 \mathrm{~b}$ & $705,99 \mathrm{~b}$ & $882,45 \mathrm{~b}$ & $954,65 \mathrm{~b}$ \\
\hline BNT 5\% & 8,96 & 11,03 & 20,29 & 25,36 & 31,44 & 51,61 \\
\hline
\end{tabular}

Keterangan: Angka-angka yang diikuti oleh huruf yang sama pada kolom yang sama menunjukan tidak berbeda nyata pada taraf uji BNT 5\%

Hasil diatas menunjukkan perkembangannya. Unsur $\mathrm{N}$ merupakan bahwapada umur 14 hst jumlah daun bagian integran dari klorofil dan yang paling tinggi ialah pada perlakuan membentuk warna hujau pada tanaman J6, hal ini disebabkan karena pada umur bila tanaman kekurangan $\mathrm{N}$, 14 hst belum terjadi persaingan karena umur dan kapasitas dalam penyerapan unsur hara masih sangat rendah, sedangkan pada umur 21 hst perlakuan J2-J6 tidak berbeda nyata, hal ini disebabkan karena tanaman jagung di tanam pada hari yang sama dan memiliki daya tumbuh yang sama. Pada umur 28-42 hst kapasitas penyerapan unsur hara semakin tinggi guna mempertahankan pertumbuhan dan pembentukan karbohidrat akan tertunda, sebaliknya jika suplai $\mathrm{N}$ cukup, pertumbuhan tanaman akan berjalan dengan baik selanjutnya karbohidrat akan terbentuk yang kemudian akan ditransformasikan menjadi protein selain itu, nitrogen juga merupakan bahan penting penyusun asam amino, amida, nukleutida, nukleuprotein, dan esensial untuk pembentukan sel, pembesaran sel, dan pembelahan sel. 
Murdaningsih: Pengaruh jarak tanam jagung terhadap pertumbuhan dan hasil jagung serta kacang tanah yang ditanam sebagai tanaman sela

Indeks Luas Daun (ILD)

Hasil analisis sidik ragam menunjukan bahwa jarak tanam memberikan pengaruh yang nyata pada ILD untuk setiap umur pengamatan (Tabel 4.4).

Tabel 4.4 Rataan ILD Pada Setiap Umur Tanaman.

\begin{tabular}{ccccccc}
\hline \multirow{2}{*}{ Perlakuan } & \multicolumn{7}{c}{ Indeks Luas Daun (cm) } & Pada Umur Pengamatan & & \\
\cline { 2 - 7 } & 14 & 21 & 28 & 35 & 42 & 49 \\
\hline J1 & $0,09 \mathrm{a}$ & $0,14 \mathrm{a}$ & $0,20 \mathrm{a}$ & $0,25 \mathrm{a}$ & $0,32 \mathrm{a}$ & $0,37 \mathrm{a}$ \\
J2 & $0,09 \mathrm{a}$ & $0,13 \mathrm{~b}$ & $0,20 \mathrm{a}$ & $0,24 \mathrm{~b}$ & $0,31 \mathrm{ab}$ & $0,36 \mathrm{ab}$ \\
J3 & $0,08 \mathrm{~b}$ & $0,13 \mathrm{~b}$ & $0,18 \mathrm{c}$ & $0,23 \mathrm{c}$ & $0,28 \mathrm{~d}$ & $0,33 \mathrm{c}$ \\
J5 & $0,07 \mathrm{c}$ & $0,12 \mathrm{c}$ & $0,19 \mathrm{~b}$ & $0,24 \mathrm{~b}$ & $0,29 \mathrm{~cd}$ & $0,34 \mathrm{bc}$ \\
J6 & $0,09 \mathrm{a}$ & $0,13 \mathrm{~b}$ & $0,19 \mathrm{~b}$ & $0,24 \mathrm{~b}$ & $0,30 \mathrm{bc}$ & $0,33 \mathrm{c}$ \\
BNT 5\% & $0,09 \mathrm{a}$ & $0,12 \mathrm{c}$ & $0,18 \mathrm{c}$ & $0,22 \mathrm{~d}$ & $0,28 \mathrm{~d}$ & $0,30 \mathrm{~d}$ \\
\hline Kete036 & 0,0046 & 0,0082 & 0,0102 & 0,0127 & 0,0213 \\
\hline
\end{tabular}

Keterangan: Angka-angka yang diikuti oleh huruf yang sama pada kolom yang sama menunjukan tidak berbeda nyata pada taraf uji BNT 5\%

Indeks Luas Daun yang paling rendah ialah pada perlakuan J1 yaitu $55 \mathrm{~cm} \times 40 \mathrm{~cm}$ dan paling tinggi ialah pada perlakuan J6 yaitu $80 \mathrm{~cm}$ x $40 \mathrm{~cm}$ sehingga meskipun luas daunnya tinggi tetapi indeksnya tetap rendah karena jarak tanamnya lebar/luas, dan sebaliknya meskipun luas daunnya rendah tetapi indeks luas daunnya tetap tinggi karena jarak tanamya sempit. Pada pengamatan indeks luas daun, yang memberikan hasil tertinggi ialah J1 meskipun ada beberapa perlakuan yang menunjukan tidak berbeda nyata pada uji BNT 5\% tetapi tetap J1 yang lebih tinggi untuk semua umur pengamatan. Hal ini disebabkan karena jarak tanam pada perlakuan J1 lebih rapat jika dibandingkan dengan perlakuan J2-J6 sehingga meskipun luas daunya tinggi, indeks luas daunnya tetap kecil karena jarak tanamnya renggang.

\section{Produksi Tanaman Jagung}

Hasil analisis sidik ragam menunjukan bahwa penggunaan jarak tanam berpengaruh sangat nyata terhadap diameter tongkol, berat tongkol $\tan ^{-1}$, berat tongkol ha ${ }^{-1}$, berat kering $\tan ^{-1}$, berat kering ${ }^{-1}$, dan berat 100 butir (Tabel 4.4). 
Murdaningsih: Pengaruh jarak tanam jagung terhadap pertumbuhan dan hasil jagung serta kacang tanah yang ditanam sebagai tanaman sela

Tabel 4.4 Pengaruh Jarak Tanam Terhadap Variabel Produksi Tanaman Jagung.

\begin{tabular}{ccccccc}
\hline \multirow{2}{*}{ Perlakuan } & $\begin{array}{c}\text { Diameter } \\
\text { Tongkol } \\
\tan ^{-1}(\mathrm{~cm})\end{array}$ & $\begin{array}{c}\text { Berat } \\
\text { Tongkol tan } \\
\text { 1(grm) }\end{array}$ & $\begin{array}{c}\text { Berat } \\
\text { Tongkol ha } \\
\text { (ton) }\end{array}$ & $\begin{array}{c}\text { Berat } \\
\text { Kering biji } \\
\text { jagung } \\
\tan ^{-1}(\mathrm{grm})\end{array}$ & $\begin{array}{c}\text { Berat Kering } \\
\text { biji jagung } \\
\text { Ha }^{-1} \text { (ton) }\end{array}$ & $\begin{array}{c}\text { Berat 100 } \\
\text { butir } \\
\text { jagung } \\
\text { (grm) }\end{array}$ \\
\hline J1 & $4,83 \mathrm{c}$ & $103,08 \mathrm{f}$ & $3,07 \mathrm{e}$ & $45,06 \mathrm{e}$ & $2,07 \mathrm{e}$ & $21,71 \mathrm{f}$ \\
J2 & $4,91 \mathrm{c}$ & $108,08 \mathrm{e}$ & $4,43 \mathrm{~d}$ & $52,00 \mathrm{~d}$ & $2,16 \mathrm{~d}$ & $23,00 \mathrm{e}$ \\
J3 & $5,25 \mathrm{~b}$ & $133,04 \mathrm{~d}$ & $4,90 \mathrm{c}$ & $66,17 \mathrm{c}$ & $2,59 \mathrm{c}$ & $25,75 \mathrm{~d}$ \\
J4 & $5,49 \mathrm{a}$ & $141,42 \mathrm{c}$ & $5,16 \mathrm{~b}$ & $70,50 \mathrm{~b}$ & $2,94 \mathrm{~b}$ & $27,84 \mathrm{c}$ \\
J5 & $5,70 \mathrm{a}$ & $171,33 \mathrm{a}$ & $5,68 \mathrm{a}$ & $80,13 \mathrm{a}$ & $3,30 \mathrm{a}$ & $32,17 \mathrm{a}$ \\
J6 & $5,52 \mathrm{a}$ & $161,25 \mathrm{~b}$ & $5,22 \mathrm{~b}$ & $74,00 \mathrm{~b}$ & $2,95 \mathrm{~b}$ & $28,50 \mathrm{~b}$ \\
\hline BNT 5\% & 0,21 & 1,34 & 0,07 & 4,96 & 0,01 & 0,48 \\
\hline
\end{tabular}

Keterangan: Angka-angka yang diikuti oleh huruf yang sama pada kolom yang sama menunjukan tidak berbeda nyata pada taraf uji BNT 5\%

\section{Produksi Tanaman Kacang Tanah}

Hasil analisis sidik ragam menunjukan bahwa jarak tanam jagung memberikan pengaruh yang nyata terhadap variabel pengamatan jumlah polong, berat polong $\tan ^{-1}$, berat polong $\mathrm{ha}^{-1}$, berat kering $\tan ^{-1}$, berat kering ha 1, dan berat 100 butir pada variabel hasil tanaman kacang tanah yang ditanam sebagai tanaman sela (Tabel $4.5)$.

Tabel 4.5 Pengaruh Jarak Tanam Jagung Terhadap Hasil Tanaman Kacang Tanah yang Ditanam Sebagai Tanaman Sela.

\begin{tabular}{ccccccc}
\hline & \multicolumn{5}{c}{ Variabel Pengamatan } \\
\cline { 2 - 7 } Perlakuan & $\begin{array}{c}\text { Jumlah } \\
\text { polong } \\
\text { (polong) }\end{array}$ & $\begin{array}{c}\text { Berat } \\
\text { Polong } \\
\tan ^{1} \\
(\mathrm{grm})\end{array}$ & $\begin{array}{c}\text { Berat } \\
\text { Polong ha } \\
\text { (ton) }\end{array}$ & $\begin{array}{c}\text { Berat Kering } \\
\tan ^{1-}(\text { grm })\end{array}$ & $\begin{array}{c}\text { Berat } \\
\text { Kering ha } \\
\text { (ton) }\end{array}$ & $\begin{array}{c}\text { Berat } 100 \\
\text { butir (grm) }\end{array}$ \\
\hline J1 & $10,88 \mathrm{e}$ & $33,00 \mathrm{c}$ & $1,49 \mathrm{f}$ & $12,25 \mathrm{f}$ & $0,55 \mathrm{f}$ & $11,04 \mathrm{f}$ \\
J2 & $12,13 \mathrm{e}$ & $36,38 \mathrm{c}$ & $1,57 \mathrm{e}$ & $15,06 \mathrm{e}$ & $0,62 \mathrm{e}$ & $12,90 \mathrm{e}$ \\
J3 & $13,94 \mathrm{~d}$ & $44,50 \mathrm{c}$ & $1,72 \mathrm{~d}$ & $20,63 \mathrm{~d}$ & $0,72 \mathrm{~d}$ & $14,40 \mathrm{~d}$ \\
J4 & $19,00 \mathrm{c}$ & $64,38 \mathrm{~b}$ & $2,32 \mathrm{c}$ & $27,25 \mathrm{c}$ & $0,90 \mathrm{c}$ & $15,84 \mathrm{c}$ \\
J5 & $26,63 \mathrm{a}$ & $88,13 \mathrm{a}$ & $3,17 \mathrm{a}$ & $31,25 \mathrm{a}$ & $1,31 \mathrm{a}$ & $19,22 \mathrm{a}$ \\
J6 & $21,18 \mathrm{~b}$ & $72,50 \mathrm{~b}$ & $2,47 \mathrm{~b}$ & $29,50 \mathrm{~b}$ & $0,95 \mathrm{~b}$ & $16,20 \mathrm{~b}$ \\
\hline BNT 5\% & 1,38 & 12,90 & 0,01 & 1,71 & 0,02 & 0,31 \\
\hline
\end{tabular}

Keterangan: Angka-angka yang diikuti oleh huruf yang sama pada kolom yang sama menunjukan tidak berbeda nyata pada taraf uji BNT 5\%

Hasil menunjukkan bahwa jarak tanam jagung memberikan pengaruh yang nyata untuk semua variabel hasil pada kacang tanah yang ditanam sebagai tanaman sela. Hal ini disebabkan karena kombinasi tanaman yang sesuai dan tidak saling merugikan antara tanaman utama dan tanaman yang ditanam sebagai tanaman sela atau sisipan, kedua komoditi ini merupakan 
Murdaningsih: Pengaruh jarak tanam jagung terhadap pertumbuhan dan hasil jagung serta kacang tanah yang ditanam sebagai tanaman sela

kombinasi antara tanaman dengan tajuk tinggi berakar dalam (jagung) dengan tajuk rendah berakar dangkal (kacang tanah). Selain itu, tanaman jagung merupakan tanaman pangan yang dapat ditanam campur dengan tanaman lain karena tajuknya kurang lebar dan tidak rimbun sehingga tidak menghalang cahaya yang masuk, sehingga tanaman lain juga mendapatkan cahaya untuk proses fotosintesis dan tidak menghalangi pertumbuhan dan perkembangan tanaman lain.

\section{Kesimpulan}

Berdasarkan hasil penelitian yang dianalisis secara statistik dengan menggunakan analisis sidik ragam, maka dapat disimpulkan bahwa:

1. Peningkatan jarak tanam jagung berpengaruh sangat nyata terhadap tinggi tanaman jagung 3,63 \%, jumlah daun jagung $0,14 \%$, luas daun jagung $32,83 \%$, indeks luas daun jagung 0,0104, diameter tongkol jagung $0,22 \%$, berat tongkol jagung $\tan ^{1-} 15,67 \%$, berat tongkol jagung $\mathrm{ha}^{-1} 0,61 \%$, berat kering jagung $\tan ^{1-} 8,24 \%$, berat kering jagung ha ${ }^{1-} 0,32 \%$, berat 100 butir biji jagung 2,83\%.

2. Jarak tanam jagung berpengaruh sangat nyata terhadap jumlah polong kacang tanah4,24 \%, berat polong kacang tanah $\tan ^{1-} 14,15 \%$, berat polong kacang tanah $\mathrm{ha}^{1-} 0,47 \%$, berat kering kacang tanah $\tan ^{1-} 4,15$ $\%$, berat kering kacang tanah $\mathrm{ha}^{1-}$ $0,23 \%$, serta berat 100 butir biji kacang tanah $2,24 \%$, yang ditanam sebagai tanaman sela.

3. Jarak tanam jagung $75 \mathrm{~cm} \mathrm{x} 40 \mathrm{~cm}$ dapat meningkatkan pertumbuhan tinggi tanaman jagung 32,08 $132,55 \mathrm{~cm}$, jumlah daun 4,17 - 9,25 helai, luas daun $266,95-995,53 \mathrm{~cm}$, ILD $0,09-0,33 \mathrm{~cm}$, diameter tongkol $5,70 \mathrm{~cm}$, berat tongkol $\tan ^{-1}$ 171,33 grm, berat tongkol ha ${ }^{1-}, 5,68$ ton, berat kering $\tan ^{-1} 80,13$ grm, berat kering $\mathrm{ha}^{-1} 3,30$ ton, berat 100 butir biji jagung 32,17 grm, dan produksi kacang tanah sebagai tanaman sela dengan jumlah polong 26,63 polong, berat polong $\tan ^{1-}$ 88,13 grm, berat polong ha- ${ }^{1} 3,17$ ton, berat kering biji tan- ${ }^{1}$ 31,25 grm, berat kering biji ha ${ }^{1-} 1,31$ ton, serta berat 100 butir 19,22 gram.

\section{Ucapan Terima Kasih}

Pada kesempatan ini penulis ingin mengucapkan terima kasih kepada semua pihak yang telah membantu dengan caranya masing-masing dalam melengkapi tulisan ini. 
Murdaningsih: Pengaruh jarak tanam jagung terhadap pertumbuhan dan hasil jagung serta kacang tanah yang ditanam sebagai tanaman sela

\section{Daftar Pustaka}

Anonymous. 2005. Bertanam Jagung Unggulan. Penebar Swadaya. Bogor.

Anonymous. 2008. Petunjuk Teknik Budidaya Tanaman Unggulan. PT Ciptawidya Swara. Jakarta Timur.

Anonymous. $2009 . \quad$ Jagung. http://id.wikipedia.org/wiki/Jagung. Disidir 04 Maret 2012.

Anonymous. 2010.Teknolgi Budidaya Jagung. http://sukatani-banguntani. blogspot. Com/2010/01/teknologibudidaya-jagung. html. Disidir 04 Maret 2012.

Ari Mayadewi. 2007. Pengaruh Jenis Pupuk Kandang dan Jarak Tanam terhadap Pertumbuhan Gulma dan Hasil Jagung.http://ejournal.ac.id. /abstrak/judul\%203\%284\%29. Pdf. Disidir 26 April 2012.

Badan Ketahanan Pangan dan Penyuluh Pertanian Kabupaten Ende. 2010. Rekapitulasi Ketersediaan Pangan Kabupaten Ende. BKP3 Ende.Ende.

Badan Ketahanan Pangan dan Penyuluh Pertanian Kabupaten Ende. 2011. Rekapitulasi Ketersediaan Pangan Kabupaten Ende. BKP3 Ende.Ende.

Baskara. 2011. Pengaruh Pemberian pupuk NPK Terhadap Pertumbuhan

Kacang.http://baskara90.wordpress. com/2011/01/03/pengaruh-

pemberian-pupuk-npk terhadappertumbuhan-kacang-jenispelanduk-dan-gajah/. Disidir 12 Maret 2012.

Candra. N. D. 2009. Mengenal Hama dan Penyakit Tumbuhan. PT Macanan Jaya Cemerlang. Klaten.

Erniyani, et al. 2008. Pengaruh Pengurangan Tongkol Tidak Berkembang Dan Pemberian Dosis Nitrogen Terhadap Hasil Tanaman Jagung (Zea mays L) Varietas
Lokal Seraya.Agrica. 1 (1): 1-5. Fakultas Pertanian Universitas Flores. Ende.

Gomez, K.A., Gomez, A. A. 1995. Prosedur Statistik Untuk Penelitian Pertanian. Edisi 2.(Sjamsumddin, E. dan Baharsjah, J. S., Pentj). Universitas Indonesia. Jakarta.

H. R. Sugeng. 2001. Bercocok Tanam Palawija. CV Aneka Ilmu. Semarang.

Praptomo Dwi, dkk. 2010. Petunjuk Teknis Pendampingan Sekolah Lapang Pengelolaan Tanaman Terpadu (SL-PTT) Jagung Di Nusa Tenggara Barat. Kementerian Pertanian Badan LITBANG Pertanian Balai Pengkajian Teknologi Pertanian NTB. Mataram.

Sedyowati. Y. T. 2007. Jenis dan Varietas Unggul Kacang Tanah.http://cybex.deptan.go.id/pe nyuluhan/jenis-dan-varietasunggul-kacang-tanah. Disidir 15 Mei 2012.

Sunarta I Wayan.2009. Pengaruh Jarak Tanam Jagung Manis Dan Varietas Kubis Terhadap Hasil Jagung Dan Kubis Pada Sistem Tumpang Sari Di Desa Candi Kuning, Tabanan.Agrica. 2 (1): 1-9. Fakultas Pertanian Universitas Flores. Ende.

Warsana. 2009. Introduksi Teknologi Tumpang Sari Jagung dan Kacang Tanah. Tabloid Sinar Tani. Jawa Tengah. 